\title{
A synoptic review of Promonobothrium Mackiewicz, 1968 (Cestoda: Caryophyllidea), parasites of suckers (Catostomidae) in North America, with description of two new species
}

\author{
Mikuláš Oros ${ }^{1,2}$, Jan Brabec ${ }^{2}$, Roman Kuchta $^{2}$, Anindo Choudhury ${ }^{3}$ and Tomáš Scholz ${ }^{2}$ \\ ${ }^{1}$ Institute of Parasitology, Slovak Academy of Sciences, Košice, Slovak Republic; \\ ${ }^{2}$ Institute of Parasitology, Biology Centre of the Czech Academy of Sciences, and Faculty of Science, University of South Bohemia, \\ České Budějovice, Czech Republic; \\ ${ }^{3}$ Division of Natural Sciences, St. Norbert College, DePere, Wisconsin, USA
}

\begin{abstract}
Monozoic cestodes of the recently amended genus Promonobothrium Mackiewicz, 1968 (Cestoda: Caryophyllidea), parasites of suckers (Cypriniformes: Catostomidae) in North America, are reviewed, with information on their host specificity, distribution and data on the scolex morphology of seven species studied for the first time using scanning electron microscopy (SEM). Evaluation of type and voucher specimens from museum collections and newly collected material of most species indicated the following valid nominal species: Promonobothrium minytremi Mackiewicz, 1968 (type species); P. ingens (Hunter, 1927); P. hunteri (Mackiewicz, 1963); P. ulmeri (Calentine et Mackiewicz, 1966); P. fossae (Williams, 1974) and P. mackiewiczi (Williams, 1974). Rogersus Williams, 1980 with its only species $R$. rogersi is transferred to Promonobothrium based on morphological and molecular data. Promonobothrium currani sp. n. and P. papiliovarium sp. n. are described from Ictiobus bubalus (Rafinesque) and Ictiobus niger (Rafinesque), and Erimyzon oblongus (Mitchill), respectively. The newly described species can be distinguished from the other congeners by the morphology of the scolex, the position of the anteriormost vitelline follicles and testes, the presence of postovarian vitelline follicles and the shape of the ovary. Molecular phylogenetic analyses of six species based on sequences of the small and large subunits of the nuclear ribosomal RNA genes (ssrDNA, 1srDNA) confirmed the monophyletic status of the genus and supported the validity of the species analysed. A key to identification of all species of Promonobothrium based on morphological characteristics is provided.
\end{abstract}

Keywords: Eucestoda, fish, comparative morphology, taxonomy, new species, Nearctic Region, identification key, molecular phylogeny

Systematic research on caryophyllidean cestodes in North America began with Hunter's (1930) extraordinary monograph of the group and reached its highest intensity in the 1960's and 1970's, when several authors such as J.S. Mackiewicz, M.J. Ulmer, R.J. Calentine and E.H. Williams described a number of caryophyllidean species and proposed several new genera (see references in Hoffman 1999). Mackiewicz in particular published the most important contributions to the current knowledge of this enigmatic group of basal tapeworms (Mackiewicz 1972, 1981, 1994, 2003). Surprisingly, almost no attention has been paid to these cestodes since the late 1980's (Scholz and Choudhury 2014), with a single species described just recently (Haley and Barger 2014).

This long period, i.e. almost three decades, of neglect by North American parasitologists is unfortunate, because caryophyllidean cestodes represent an interesting model for studies of unusual molecular and cytogenetic phenome- na (Králová-Hromadová et al. 2010, Špakulová et al. 2011, Brabec et al. 2012), and phenotypic, possibly host-related plasticity of some species (Barčák et al. 2014, Bazsalovicsová et al. 2014, Hanzelová et al. 2015).

Based on morphological and molecular data, Scholz et al. (2015) transfered five Nearctic species previously placed in Monobothrium Diesing, 1863, to the originally monotypic Promonobothrium Mackiewicz, 1968. However, the taxonomic status of these species has not been critically assessed. In this paper, results of a taxonomic study on amended Promonobothrium are presented and a key to identification of its species is provided. In addition, two new species of Promonobothrium are described from smallmouth buffalo Ictiobus bubalus (Rafinesque) and black buffalo Ictiobus niger (Rafinesque) in Mississippi, and from eastern creek chubsucker Erimyzon oblongus (Mitchill) in North Carolina, USA, respectively, and interrelationships of species of Promonobothrium are assessed.

Address for correspondence: T. Scholz, Institute of Parasitology, Biology Centre of the Czech Academy of Sciences, Branišovská 31 , 370 05 České Budějovice, Czech Republic. Phone: +420 385310 351; Fax: +420 385310 388; E-mail: tscholz@paru.cas.cz

Zoobank number for article: urn:lsid:zoobank.org:pub:BF15D5DD-4B50-477D-984F-8AA30117AC13 
Table 1. List of specimens of species of Promonobothrium Mackiewicz, 1968 sequenced.

\begin{tabular}{|c|c|c|c|c|}
\hline \multirow{2}{*}{ Specimen } & \multirow{2}{*}{ Host } & \multirow{2}{*}{ Locality (USA) } & \multirow{2}{*}{ Voucher } & \multirow{2}{*}{$\begin{array}{c}\text { GenBank Accession } \\
\text { ssrDNA/lsrDNA }\end{array}$} \\
\hline & & & & \\
\hline Promonobothrium currani sp. $\mathrm{n}$. & Ictiobus niger (Rafinesque) & Chotard Lake, Mississippi & PBI-410 & KU665563/KU665574 \\
\hline Promonobothrium currani sp. $\mathrm{n}$. & Ictiobus bubalus (Rafinesque) & Chotard Lake, Mississippi & US $245 \mathrm{a}$ & KU665570/KU665581 \\
\hline $\begin{array}{l}\text { Promonobothrium hunteri } \\
\text { (Mackiewicz, 1963) }\end{array}$ & $\begin{array}{l}\text { Hypentelium nigricans } \\
\text { (Lesueur) }\end{array}$ & West Twin River, Wisconsin & PBI-422 & KU665564/KU665575 \\
\hline Promonobothrium hunteri & Moxostoma poecilurum Jordan & Pascagoula River, Mississippi & PBI-466 & KU665565/KU665576 \\
\hline Promonobothrium hunteri & $\begin{array}{l}\text { Catostomus commersonii } \\
\text { (Lacepède) }\end{array}$ & Duck Creek, Wisconsin & DP 135/09-II & KU665561/KU665572 \\
\hline $\begin{array}{l}\text { Promonobothrium ingens } \\
\text { (Hunter, 1927) }\end{array}$ & $\begin{array}{l}\text { Moxostoma anisurum } \\
\text { (Rafinesque) }\end{array}$ & Wolf River, Wisconsin & DP 115/09-II & KU665560/KU665571 \\
\hline $\begin{array}{l}\text { Promonobothrium minytremi } \\
\text { Mackiewicz, } 1968\end{array}$ & $\begin{array}{l}\text { Minytrema melanops } \\
\text { (Rafinesque) }\end{array}$ & Wolf River, Wisconsin & PBI-406 & KU665562/KU665573 \\
\hline Promonobothrium minytremi & Minytrema melanops & Pascagoula River, Mississippi & US $178 b$ & KU665566/KU665577 \\
\hline Promonobothrium minytremi & Minytrema melanops & Pascagoula River, Mississippi & US 209a & KU665568/KU665580 \\
\hline Promonobothrium minytremi & Minytrema melanops & Pascagoula River, Mississippi & US 209a-d & KU665569/KU665579 \\
\hline $\begin{array}{l}\text { Promonobothrium rogersi } \\
\text { (Williams, 1980) comb. } \mathrm{n} .\end{array}$ & Carpiodes velifer (Rafinesque) & Pascagoula River, Mississippi & US 191 & KU665567/KU665578 \\
\hline
\end{tabular}

PBI-No. - unique specimen ID to a NSF project, see http://www.tapewormdb.uconn.edu/index; US No. and DP No. - unique field ID of the hosts.

\section{MATERIALS AND METHODS}

\section{Specimens studied}

Material of the following species was studied: Promonobothrium minytremi Mackiewicz, 1968 (type species); P. ingens (Hunter, 1927); P. hunteri (Mackiewicz, 1963); P. ulmeri (Calentine et Mackiewicz, 1966); P. fossae (Williams, 1974); P. mackiewiczi (Williams, 1974); and Rogersus rogersi Williams, 1980. New material was collected during field expeditions of the authors (A.C., R.K. and M.O.) and their collaborators in North America in Mississippi, South Carolina, Texas and Wisconsin, USA, in 2010, 2012 and 2013.

\section{Morphological evaluation}

Tapeworms collected recently by the present authors were processed using the methods described by Oros et al. (2010). Briefly, live tapeworms were isolated from the host intestine and rinsed in saline. Hot (almost boiling) 4\% neutral buffered formaldehyde solution $(=10 \%$ buffered formalin) was added into the beaker or vial with the worms as soon as possible. After 2-3 weeks, tapeworms were transferred to $70 \%$ ethanol before further processing.

The specimens were stained with Mayer's hydrochloric carmine solution, dehydrated through graded ethanol series, cleared in clove oil (eugenol) and mounted in Canada balsam as permanent preparations. Line drawings were made using a drawing attachment on a Leica DM 5000B light microscope, with the use of Nomarski interference contrast. Measurements were taken using the LAS V3.8ink (Leica) programme. All measurements are given in micrometres unless otherwise indicated. Pieces of worms to be sectioned were embedded in paraffin wax, cross-sectioned at $12-15 \mu \mathrm{m}$, stained with Weigert's haematoxylin, and counterstained with $1 \%$ eosin B following recently updated protocols (Oros et al. 2010).

Several specimens were prepared for scanning electron microscopy (SEM) following the procedure outlined by Oros et al. (2010) using a Jeol JSM 6510LA Scanning Electron Microscope. SEM photomicrographs of the newly described species from Erimyzon oblongus were taken from stained whole-mounted specimens that were remounted from Canada balsam. Scanning electron micrographs of all but two species ( $P$. fossae and P. mackiewiczi) of Promonobothrium were used for SEM obser- vations. Terminology of microtriches follows Chervy (2009) and terminology of molecular vouchers follows Pleijel et al. (2008).

\section{Deposition of specimens}

Specimens studied are deposited in the following collections: the Helminthological Collection of the Institute of Parasitology, Biology Centre of the Czech Academy of Sciences, České Budějovice, Czech Republic (acronym IPCAS), the Harold W. Manter Laboratory, University of Nebraska Museum, Lincoln, USA (HWML), the Natural History Museum, London, UK (NHMUK), and the National Museum of Natural History (NMNH) at the Smithsonian Institution, Washington, D.C., USA.

\section{Molecular data generation and analyses}

The mid-portion of the collected worm specimens was fixed in $96 \%$ molecular-grade ethanol (anterior and posterior regions were fixed with hot formalin as described above and preserved as vouchers) and subsequently used for extraction of genomic DNA (see Table 1 for list of samples). The protocol for DNA isolation, PCR amplification of the nuclear ribosomal RNA genes (ssrDNA, 1srDNA) and sequencing followed the protocol of Brabec et al. (2012). Contiguous sequences were assembled using Geneious version 7 (http://www.geneious.com/, Kearse et al. 2012) and single-gene alignments created using the E-INS-i algorithm of the program MAFFT (Katoh and Standley 2013) implemented therein. Ambiguously aligned positions were manually excluded from subsequent analyses.

Phylogenetic relationships were estimated from a concatenated dataset using maximum likelihood (ML) and Bayesian inference (BI) methods. Best fitting models of nucleotide evolution were selected using the small sample size corrected Akaike information criterion in PartitionFinder 1.1.0 (Lanfear et al. 2012). The best ML estimate was obtained from 100 searches in the program GARLI ver. 2.01 (Zwickl 2006; see Fig. 4 legend for model specifications). ML bootstrap support was computed by running 5 searches on each of the 100 bootstrap resamples in GARLI. A BI tree was constructed using MrBayes ver. 3.2 (Ronquist et al. 2012), running 4 independent MC3 runs of 4 chains for 20 million generations, sampling tree topologies every 1000 th generation, and using the same partitioning scheme and model as in the ML analysis. Burn-in fraction was set to 0.25 . 


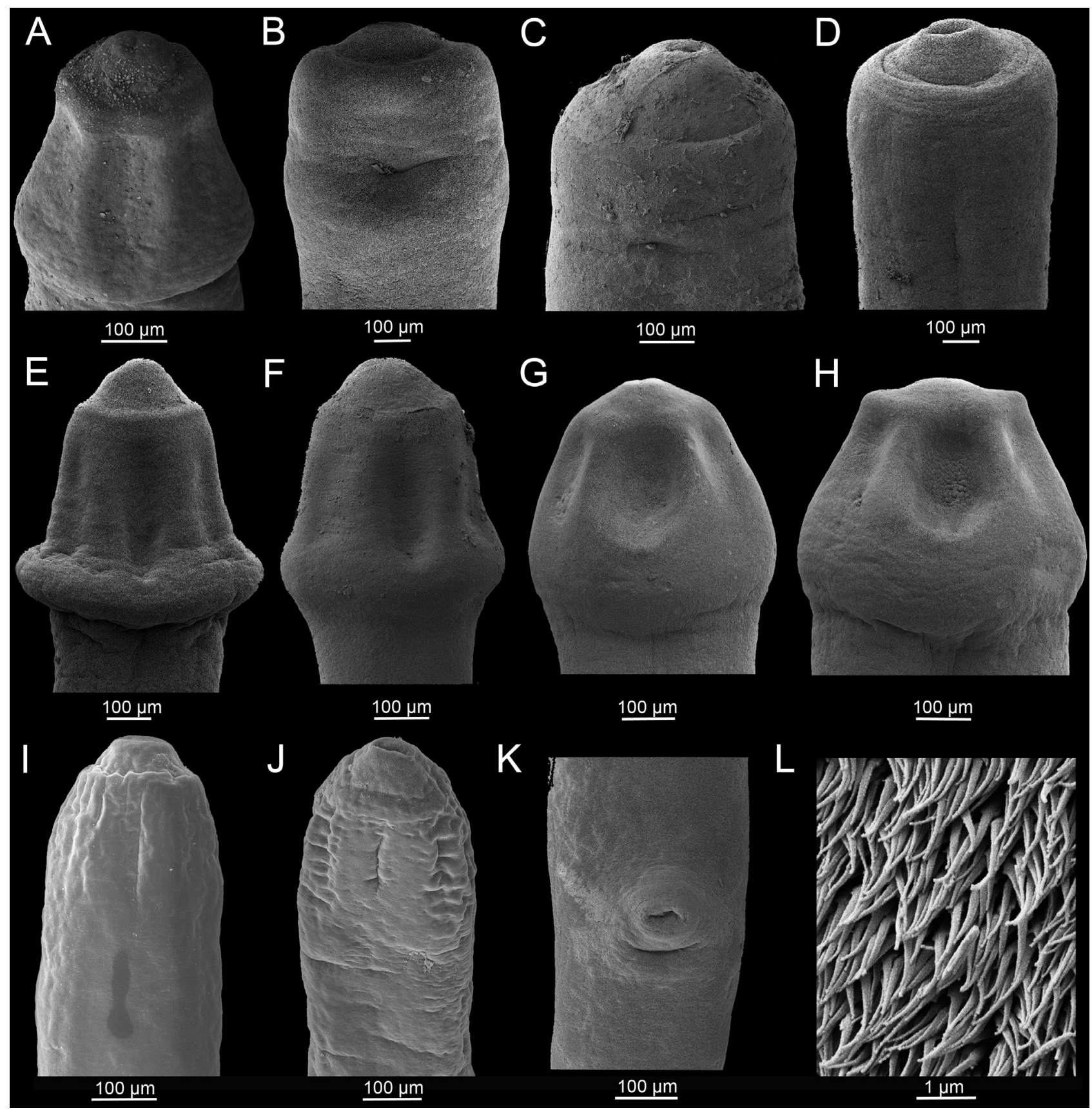

Fig. 1. Scanning electron micrographs of species of Promonobothrium (A-J - scolex only, K - gonopores, $\mathrm{L}$ - acicular filitriches). A - Promonobothrium minytremi Mackiewicz, 1968 from Minytrema melanops (Rafinesque); B - P. ingens (Hunter, 1927) from Carpiodes cyprinus (Lesueur); C - P. hunteri (Mackiewicz, 1963) from Hypentelium nigricans (Lesueur); D - P. ulmeri (Calentine et Mackiewicz, 1966) from Minytrema melanops (from Scholz et al. 2015); E, F, K, L - P. currani sp. n. from Ictiobus bubalus (Rafinesque); G, H - P. rogersi (Williams, 1980) comb. n. from Carpiodes velifer (Rafinesque); I, J - P. papiliovarium sp. n. from Erimyzon oblongus (Mitchill).

\section{RESULTS}

Promonobothrium comprises the following 9 species: P. minytremi (type species), P. ingens, P. hunteri, P. ulmeri, $P$. fossae, P. mackiewiczi, P. rogersi (for Rogersus rogersi) and two new species described below. A synopsis of these species (listed chronologically after type species) with information on their taxonomic status, definitive hosts, life cycle and geographical distribution is provided below, together with new data on scolex morphology from SEM.
Promonobothrium Mackiewicz, 1968

Synonyms: Monobothrium Diesing, 1863 partim (species from the Nearctic region), Rogersus Williams, 1980 (new synonym)

Type species: Promonobothrium minytremi Mackiewicz, 1968

Amended generic diagnosis of Promonobothrium: Caryophyllidea: Caryophyllaeidae. Body elongated to digitiform. Surface uniformly covered with acicular fil- 
itriches. Inner longitudinal musculature well developed. Scolex digitiform, digitiform-loculate or loculotruncate, with a terminal introvert on apex. Neck short to moderately long. Testes medullary. Cirrus-sac small, oval or spherical. External seminal vesicle present. Ovary follicular, H-shaped or butterfly-shaped. Seminal receptacle absent. Vitelline follicles medullary, lateral and median. Postovarian follicles absent or present. Uterus does not loop anterior to cirrus-sac. Male and female gonopores separate. Uterine glands present. Eggs operculate, unembryonated. Parasites of suckers (Catostomidae) in North America.

Selected references: Mackiewicz $(1968,1994)$, Scholz et al. (2015).

Remarks. Promonobothrium was erected by Mackiewicz (1968) for its type and single species $P$. minytremi from Minytrema melanops (Rafinesque) in the Blue River, Oklahoma, USA. In a recent molecular phylogenetic analysis (Scholz et al. 2015), P. minytremi appears in a monophyletic lineage comprising caryophyllidean species from the Nearctic zoogeographical region originally described in Monobothrium. Therefore, these species have been transferred to the originally monotypic Promonobothrium. Moreover, Rogersus Williams, 1980 with its type species is transferred to Promonobothrium as a new combination, and two new species of Promonobothrium are described herein, thus increasing the total number of species in the genus to nine.

Promonobothrium minytremi Mackiewicz, 1968 type species

Type and only host ${ }^{1}$ : Spotted sucker Minytrema melanops* (Rafinesque) (Catostominae).

Type locality: Blue River, Connerville, Johnston Co., Oklahoma, USA.

Distribution: USA - Mississippi, Oklahoma and South Carolina.

Museum material studied: One paratype (USNPC 70930), two vouchers from the Blue River, Connerville, OK, USA (USNPC 70931).

Newly collected material: Eight specimens from M. melanops (host field numbers US 178 and US 209) in the Pascagoula River near Benndale, MS (IPCAS C-552), and from M. melanops (US 283 - paragenophores) in the Congarec River, SC, USA, 2012 (IPCAS C-552).

Reference: Mackiewicz (1968).

Remarks. The type species of the genus was described from Minytrema melanops in the Blue River, Oklahoma, USA. This species has been found only in type host (M. melanops) (Mackiewicz 1968, Hoffman 1999; present study). Mackiewicz (1968) noted morphological similarity of P. minytremi and the Nearctic species of Monobothrium which possess separate gonopores and lack postova5rian vitelline follicles. Promonobothrium minytremi was differentiated from these species of Monobothrium by the absence of a terminal introvert on the scolex and a postovarian loop of the vitelloduct (fig. 8 in Mackiewicz 1968). Recently collected specimens of $P$. minytremi from $M$. melanops are identical with those described by Mackiewicz (1968).

Promonobothrium ingens (Hunter, 1927) Scholz, Oros, Choudhury, Brabec et Waeschenbach, 2015

Fig. 1B

Synonym: Monobothrium ingens Hunter, 1927

Ty p e hos t: Bigmouth buffalo Ictiobus cyprinellus* (Valenciennes) (Ictiobinae).

Additional hosts: Quillback Carpiodes cyprinus* (Lesueur) (Ictiobinae) (new host record), White sucker Catostomus commersonii (Lacepède) (Catostominae), Smallmouth buffalo Ictiobus bubalus (Rafinesque) (Ictiobinae), Silver redhorse Moxostoma anisurum* (Rafinesque) (Catostominae) (new host record).

Type locality: Lake Pepin, Minnesota, USA.

D i s tributi on: USA - Minnesota, New York, Ohio, Oklahoma, Tennessee and Wisconsin.

Museum material examined: One voucher from I. cyprinellus (host number 821.8 , locality not known), USA (IPCAS C-583).

Newly collected material: One specimen from C. cyprinus (DP 89/09 - paragenophore) in Lake Winnebago, WI; one specimen from M. anisurum (DP 115/09) in the Wolf River, WI, USA, 2009 (all IPCAS C-583).

Selected references: Hunter (1927, 1930), Bangham and Venard (1942), Calentine (1967), Williams (1978).

Remarks. Hunter (1927), who started the complex systematic research on caryophyllidean cestodes in North America, described three new genera and four new species, including $P$. ingens (as Monobothrium ingens) from Ictiobus cyprinella ( $=$ I. cyprinellus) (Valenciennes) in Lake Pepin, Minnesota. This author also amended the generic diagnosis of Monobothrium, which, at the time, contained only the European M. wageneri Nybelin, 1922 from tench, Tinca tinca (Linnaeus), to reflect some different morphological characteristics of these species from suckers (Catostomidae) in the Nearctic region, such as the scolex with a terminal funnel-shaped introvert, an external seminal vesicle (absent in $M$. wageneri) and absence of postovarian vitellaria (Hunter 1927, 1930).

Two other suckers, namely C. commersonii (Lacepède) and $I$. bubalus, have been reported as definitive hosts of P. ingens (see Hoffman 1999). These hosts have not been confirmed by the present study, but the cestode was found in new hosts, namely C. cyprinus from Lake Winnebago and M. anisurum (Rafinesque) from the Wolf River, both in Wisconsin, which indicates a rather wide (metastenoxenous) host specificity of $P$. ingens.

\section{Promonobothrium hunteri (Mackiewicz, 1963)}

Scholz, Oros, Choudhury, Brabec et Waeschenbach, 2015 Fig. 1C

Synonym: Monobothrium hunteri Mackiewicz, 1963

Type host: Catostomus commersonii* (Lacepède, 1803).

${ }^{1}$ Hosts confirmed by the present authors marked with an asterisk. 
Additional hosts: Carpiodes cyprinus (Lesueur), Bluehead sucker Catostomus discobolus Cope, Flannelmouth sucker C. latipinnis Baird et Girard (Catostominae), Northern hog sucker Hypentelium nigricans* (Lesueur) (new host record), Shorthead redhorse Moxostoma macrolepidotum (Lesueur) (Catostominae).

Type locality: Outlet from Dryden Lake, Dryden, Tompkins Co., New York, USA.

Distribution: Canada - British Columbia; USA - Connecticut, Kentucky, Michigan, Nebraska, New York, North Carolina, North Dakota, Pennsylvania, Utah, West Virginia, Wisconsin and Wyoming.

Museum material examined: One paratype from C. commersonii in Cascadilla Creek (USNPC 59867), one voucher from C. commersonii in Beebe Lake, Ithaca, NY (USNPC 59871), one voucher (immature specimen) from C. commersonii from WI (IPCAS C-505) and two vouchers from M. macrolepidotum, NE, USA (HWML 20455).

Newly collected material: Two specimens from C. commersonii in the West Twin River, near Maribel, WI (DP 1/09 paragenophore) and in Duck Creek, De Pere, WI (DP 135/09), and one specimen from $H$. nigricans (new host record) in the Waupaca River, WI, USA, 2009 (DP 158/09 hologenophore; all IPCAS C-505).

Selected references: Mackiewicz (1963), Calentine (1967), Williams (1977).

Remarks. This species was described as Monobothrium hunteri by Mackiewicz (1963), who pointed out marked differences between the Palaearctic (M. auriculatum Kulakovskaya, 1961, now Caryophyllaeus - see Scholz et al. 2015 and M. wageneri) and Nearctic (M. ingens and M. hunteri, now in Promonobothrium - see Scholz et al. 2015) species of Monobothrium in their morphology and host associations, thus indicating that the genus may be an artificial assemblage of unrelated taxa.

Promonobothrium hunteri may possess 1-2 postovarian vitelline follicles in some cases, which are always associated with the postovarian loop of the vitelloduct (Mackiewicz 1963). In the present study, two postovarian vitelline follicles were observed in one specimen collected from C. commersonii in the West Twin River. Hypentelium nigricans (Lesueur) represents a new fish host record for P. hunteri.

Promonobothrium ulmeri (Calentine et Mackiewicz, 1966) Scholz, Oros, Choudhury, Brabec et

Waeschenbach, 2015

Figs. 1D, 4C,F

Synonym: Monobothrium ulmeri Calentine et Mackiewicz, 1966

Type host: Hypentelium nigricans (Lesueur).

Additional hosts: Eastern creek chubsucker Erimyzon oblongus (Mitchill), Moxostoma anisurum (Rafinesque), Golden redhorse M. erythrurum (Rafinesque), M. macrolepidotum (Lesueur), Minytrema melanops* (Rafinesque) (all Catostominae).

Intermediate host: Limnodrilus hoffmeisteri Claparède (Oligochaeta: Tubificidae).

Type locality: South Fork of the Iowa River, Hardin Co., Iowa, USA.

Distribution: USA - Georgia, Iowa, Mississippi, North
Carolina, Oklahoma and Wisconsin.

Museum material examined: One paratype from H. nigricans (USNPC 60741), one paratype from M. erythrurum (USNPC 60742), one voucher from $H$. nigricans, IA (locality not known) (USNPC 60743), one voucher from $E$. oblongus in the Swift Creek, NC (USNPC 73741), 27 vouchers from E. oblongus from NC (HWML 33253, 33254, 33256 and 33257), one voucher from M. macrolepidotum in the Red Cedar River, WI, USA (USNPC 74917).

Newly collected material: Three specimens from M. melanops (US 217a - hologenophore) in the Pascagoula River near Benndale, Mississippi, USA, 2012 (IPCAS C-505).

Selected references: Calentine and Mackiewicz (1966), Williams (1974), Grimes and Miller (1975).

Remarks. Promonobothrium ulmeri was described as Monobothrium ulmeri from three species of catostomid fishes, namely Hypentelium nigricans (type host), Moxostoma anisurum and M. erythrurum. The new species was differentiated from its Nearctic congeners by the absence of distinct loculi ( $v s$ the scolex with a pair of distinct loculi in $P$. ingens) and greater number of testes (350-570 in P. ulmeri vs 70-120 in P. hunteri), different hosts, i.e. species of Moxostoma Rafinesque and Hypentelium Rafinesque for P. ulmeri and Catostomus commersonii for $P$. hunteri.

Calentine and Mackiewicz (1966) also studied the early development of $P$. ulmeri from the release of eggs to the formation of infective plerocercoids in the oligochaete intermediate hosts, Limnodrilus hoffmeisteri Claparède and Tubifex templetoni Southern, under laboratory conditions. Infectivity of oncospheres was confirmed by successful experimental infection of L. hoffmeisteri (infected 26 of 70 exposed, i.e. $37 \%$ ) only.

Promonobothrium fossae (Williams, 1974) Scholz, Oros, Choudhury, Brabec et Waeschenbach, 2015

Synonym: Monobothrium fossae Williams, 1974

Type and only host: Blacktail redhorse Moxostoma poecilurum Jordan (Catostominae).

Type locality: Uphapee Creek, north of Tuskegee, Macon Co., Alabama, USA.

Distribution: USA - Alabama.

Museum material examined: One paratype from M. poecilurum in the Uphapee Creek, AL, USA (USNPC 72463).

Newly collected material: None

R e fer e n c e: Williams (1974); the cestode has not been found since its original description.

Remarks. See comments on P. mackiewiczi.

Promonobothrium mackiewiczi (Williams, 1974)

Scholz, Oros, Choudhury, Brabec et Waeschenbach, 2015

Synonym: Monobothrium mackiewiczi Williams, 1974

Type and only host: Alabama hog sucker Hypentelium etowanum (Jordan) (Catostominae).

Type locality: Kowalinga Creek, Coosa Co., Alabama, 
USA.

Distribution: USA-Alabama.

Museum material examined: Two paratypes from H. etowanum in the Kowalinga Creek, AL, USA (USNPC 72465 and 72466).

Newly collected material: None.

Reference: Williams (1974); the species has not been found since its original description.

Remarks. Two caryophyllidean cestodes, Promonobothrium fossae and P. mackiewiczi, were described as Monobothrium fossae and M. mackiewiczi by Williams (1974) from Moxostoma poecilurum Jordan and Hypentelium etowanum (Jordan), in Alabama, respectively. In addition, a table comparing five North American species of Monobothrium (all currently in Promonobothrium) was presented. The two species were differentiated from each other by a smaller body and more testes in $P$. fossae (259-364 testes vs 138-179 testes in P. mackiewiczi), and in their manner of attaching to the host gut: several worms together in mucosal pits in the case of $P$. fossae vs firm attachment of individual worms in $P$. mackiewiczi. Both species most closely resemble $P$. ulmeri in having a digitiform scolex, a long neck and no postovarian vitelline follicles, and differ only in a different number of testes (as much as 643 in P. ulmeri vs 364 and 179 in P. fossae and $P$. mackiewiczi, respectively) and osmoregulatory canals (10 in P. ulmeri vs 8 and 16 in P.fossae and P. mackiewic$z i$, respectively) (see table 1 in Williams 1974).

Because of the lack of newly collected material of $P$. fossae and P. mackiewiczi, including ethanol preserved material, both species are provisionally retained as valid but future studies may reveal their possible conspecificity with other congeners.

Promonobothrium rogersi (Williams, 1980) comb. n. Figs. $1 \mathrm{G}, \mathrm{H}, 3 \mathrm{E}, 4 \mathrm{~B}, \mathrm{E}, \mathrm{G}$

Synonym: Rogersus rogersi Williams, 1980

ZooBank number for species:

urn:1sid:zoobank.org:act:17D002BD-2C59-42A8-882A-1E1ED411BD20

Type host: Moxostoma poecilurum Jordan (Catostominae).

Additional host: Highfin carpsucker Carpiodes velifer* (Rafinesque) (Ictiobinae) (new host).

Type locality: Pea River, Geneva, Coffee Co., Alabama, USA.

Distribution: USA - Alabama and Mississippi.

Museum material examined: Holotype (USNPC 74854) and four paratypes (USNPC 74855) from M. poecilurum in the Pea River, AL, USA.

Newly collected material: Eight specimens from C. velifer (host field Nos. US 191 - hologenophore, US 216 a - paragenophores, US 186-95) in the Pascagoula River near Benndale, MS, USA, 2012 (NHMUK 2016.2.22.3-4, IPCAS C-698, HWML 101979-80).

Reference: Williams (1980); the species is recorded for the first time since its original description.
Remarks. The monotypic genus Rogersus is now transferred to Promonobothrium as a new combination based on morphological characters typical of Promonobothri$u m$ and molecular data. The specimens from the new fish host, C. velifer, collected in Mississippi for this study, fully correspond to those described as Rogersus rogersi from $M$. poecilurum from the original description, for which Williams (1980) erected a new genus, Rogersus. We acknowledge the differences in host and geography (but both drainages are southern), but the specimens studied by the present authors are morphologically indistinguishable from those of $R$. rogersi in taxonomically important characteristics. In addition, we based our species identification on comparison of our specimens with types of this species, including its holotype, and present evidence of some features present in the type species that are absent in the original description. As shown for P. hunteri (see above) and other caryophyllideans, some species exhibit a relatively low host specificity, which may be the case of $R$. rogersi.

Rogersus rogersi was typified among other characteristics by the possession of a scolex with a pair of median acetabular suckers (biacetabulate, see fig. 5.13 in Mackiewicz 1994 for scolex types) and two pairs of lateral loculi. However, scanning electron micrographs (Fig. 1G,H) and histological section of the scolex (Fig. 4G) of the newly collected specimens from $C$. velifer demonstrated a loculotruncate scolex, i.e. distinct scolex, wider than neck, with a pair of median loculi, two lateral depressions and with a terminal introvert on apex, rather than acetabula, sucker-like attachment organs with a membrane-bounded structure, typical for the 'higher' or 'acetabulate' cestodes, e.g. Proteocephalidea, Nippotaeniidea, Tetrabothriidea, Cyclophyllidea (Caira et al. 2012). Moreover, this species was typified by the absence of the external seminal vesicle (see Mackiewicz 1994), but a study of the type material including holotype, as well as the newly collected material including sagittal section (see Figs. 3E, 4E), demonstrated the presence of an external seminal vesicle that is typical for the species of Promonobothrium.

\section{Promonobothrium currani sp. n.}

Figs. 1E,F,K,L, 2A, 3A,B, 4A,D

ZooBank number for species:

urn:1sid:zoobank.org:act:0808AA4A-6577-4AA1-9CAA-ABC3245A33B1

Description (based on five whole-mounted specimens from Ictiobus bubalus and one whole-mount from I. niger - in parentheses - both from Chotard Lake, Mississippi, USA): Body elongate, with narrow neck, total length of body $21.5-25.0 \mathrm{~mm}$, maximum width $0.8 \mathrm{~mm}(0.8 \mathrm{~mm})$ at level posterior to cirrus-sac, tapering continuously towards anterior end (Fig. 2A). Surface uniformly covered with acicular filitriches (Fig. 1L). Inner longitudinal musculature well-developed, formed by small bundles of muscle fibres (Fig. 4A). Osmoregulatory canals narrow, forming about 10 pairs external to vitelline follicles (Fig. 4A) 
Table 2. Measurements of new species of Promonobothrium Mackiewicz, 1968.

\begin{tabular}{|c|c|c|c|}
\hline & P. currani sp. n. & P. currani sp. $\mathrm{n}$. & P. papiliovarium $\mathrm{sp} . \mathrm{n}$. \\
\hline \multirow[t]{2}{*}{ Characters/Promonobothrium spp. } & Ictiobus bubalus (Rafinesque) (type host) & Ictiobus niger (Rafinesque) & Erimyzon oblongus (Mitchill) \\
\hline & present study $(\mathrm{n}=5)$ & present study $(\mathrm{n}=1)$ & present study $(\mathrm{n}=7)$ \\
\hline Body length (mm) & $21.5-25.0$ & - & $17.0-50.5$ \\
\hline maximum width & 0.8 & 0.8 & 0.8 \\
\hline Scolex shape & distinct, loculotruncate & distinct, loculotruncate & indistinct, digitiform \\
\hline length & $640-986$ & 750 & - \\
\hline width & $630-864$ & 752 & $262-623$ \\
\hline Neck width $(\mu \mathrm{m})$ & $306-501$ & 407 & $369-694$ \\
\hline Testis size & $117-191 \times 112-155$ & $145-171 \times 126-141$ & $114-212 \times 94-204$ \\
\hline number & $177-255$ & - & $212-253$ \\
\hline distance from first vitelline follicle $(\mathrm{mm})$ & 2.1-2.6 & 2.6 & $1.1-6.3$ \\
\hline distance from anterior extremity $(\mathrm{mm})$ & $9.2-10.7$ & 9.5 & $3.4-14.6$ \\
\hline reach up to & anterior part of CS & anterior part of CS & anterior part of CS \\
\hline length of testicular field (mm) & $9.5-11.7$ & & $9.5-33$ \\
\hline Cirrus-sac (CS) shape & oval & oval & spherical \\
\hline size & $343-404 \times 287-401$ & $320-398$ & $276-494 \times 261-490$ \\
\hline extent in relation to the width of body & $1 / 2$ & $1 / 2$ & $1 / 30-1 / 25$ \\
\hline Ovary shape & $\mathbf{H}$ & $\mathbf{H}$ & butterfly \\
\hline width & $563-690$ & 587 & $432-969$ \\
\hline length of ovarian arms & $714-971$ & $772-811$ & $668-1446$ \\
\hline width of ovarian arms & $140-250$ & $181-183$ & $146-364$ \\
\hline length of anterior ovarian arms & $246-445$ & 264-287 & $364-1001$ \\
\hline length of posterior ovarian arms & $152-316$ & $224-229$ & $86-326$ \\
\hline Vitelline follicle size & $104-156 \times 67-104$ & $106-132 \times 77-104$ & $80-189 \times 56-139$ \\
\hline distance from anterior extremity $(\mathrm{mm})$ & $7.1-8.1$ & 6.9 & $2.2-8.3$ \\
\hline reach up to & posterior part of CS & posterior part of CS & posterior part of CS \\
\hline Uterus extent (mm) & $1.7-1.8$ & 1.6 & $1.5-3.5$ \\
\hline in relation to length of testicular area & $1 / 7-1 / 6$ & - & $1 / 8-1 / 7$ \\
\hline Size of intrauterine eggs & $48-60 \times 37-45$ & $50-58 \times 33-39$ & $43-58 \times 32-37$ \\
\hline External seminal vesicle & present & present & present \\
\hline Receptaculum seminis & long, narrow & long, narrow & long, narrow \\
\hline Genital pores & separate & separate & separate \\
\hline Postovarian vitelline follicles & present & present & absent \\
\hline
\end{tabular}

Values in bold indicate differences between the species.

Scolex loculotruncate (see fig. 5.3 in Mackiewicz 1994 for scolex types), distinct, well separate from body, 640-986 (750) long and 630-864 (752) wide, with pair of shallow median loculi, two lateral depressions and with a terminal introvert on apex (Figs. 1E,F, 3A). Neck distinct, long, 306-501 (407) wide.

Testes medullary (Fig. 4A), 177-255 in number $(\mathrm{n}=4)$, almost spherical, 117-191 × 112-155 (145-171 $\times 126-141)(\mathrm{n}=50)$; anteriormost testes begin at long distance, $9.2-10.7 \mathrm{~mm}(9.5 \mathrm{~mm})$, posterior to anterior extremity and $2.1-2.6 \mathrm{~mm}(2.6 \mathrm{~mm})$ posterior to anteriormost vitelline follicles (Figs. 2A, 3A). Testicular field ends at level of anterior margin of cirrus-sac (Fig. 3B). Cirrus-sac small, oval, 343-404 × 287-401 $(320 \times 398)$, its width representing about $1 / 2(1 / 2)$ of body width. External seminal vesicle present, thick-walled, elongate, forming a few coils (Figs. 3B, 4D). Male genital pore separate, anterior to female pore; distance between pores 92-156 (103) (Fig. 1K).

Ovary follicular, medullary, H-shaped (Fig. 3B), with almost equal length of ovarian arms, 714-971 (772-811) long; total width of ovary 563-690 (587). Vagina tubular, slightly sinuous, forms with terminal part of uterus short uterovaginal canal opening by female genital pore posterior to male genital pore. Seminal receptacle absent. Vitelline follicles medullary, numerous, vary in size, 104-156 $\times 67-104(106-132 \times 77-104)(\mathrm{n}=50)$, anterior to first testes, begin at long distance, 7.1-8.1 (6.9) $\mathrm{mm}$, posterior to anterior extremity, extend up to level of midline or posterior end of cirrus-sac, absent alongside uterus and ovarian arms (Figs. 2A, 3B). Preovarian vitelline follicles lateral and median, surrounding testes, postovarian follicles present, 14-19 (16) in number (Fig. 3B).

Uterus forms several loops between postovarian vitelline follicles and posterior margin of cirrus-sac, never extending anterior to cirrus-sac, joins vagina to form wide uterovaginal canal. Uterine glands present, well developed. Eggs operculate, unembryonated, oval, 48-60 × 33-45 $(50-58 \times 33-39)(\mathrm{n}=30$, intrauterine eggs on wholemounts).

Type host: Ictiobus bubalus (Rafinesque) (Catostomidae: Ictiobinae).

Other host: Ictiobus niger (Rafinesque) (Catostomidae: Ictiobinae).

Site of infection: Anterior intestine.

Type locality: Chotard Lake near Vicksburg, Warren County $\left(32^{\circ} 34^{\prime} 33^{\prime \prime} \mathrm{N} ; 91^{\circ} 02^{\prime} 48^{\prime \prime} \mathrm{W}\right)$, located at the lower reach of the Mississippi River basin, Mississippi, USA.

Other locality: Pascagoula River near Benndale, George County $\left(30^{\circ} 52^{\prime} 18^{\prime \prime} \mathrm{N} ; 88^{\circ} 48^{\prime} 25^{\prime \prime} \mathrm{W}\right)$, located at the lower reach of the Mississippi River basin, Mississippi, USA. 


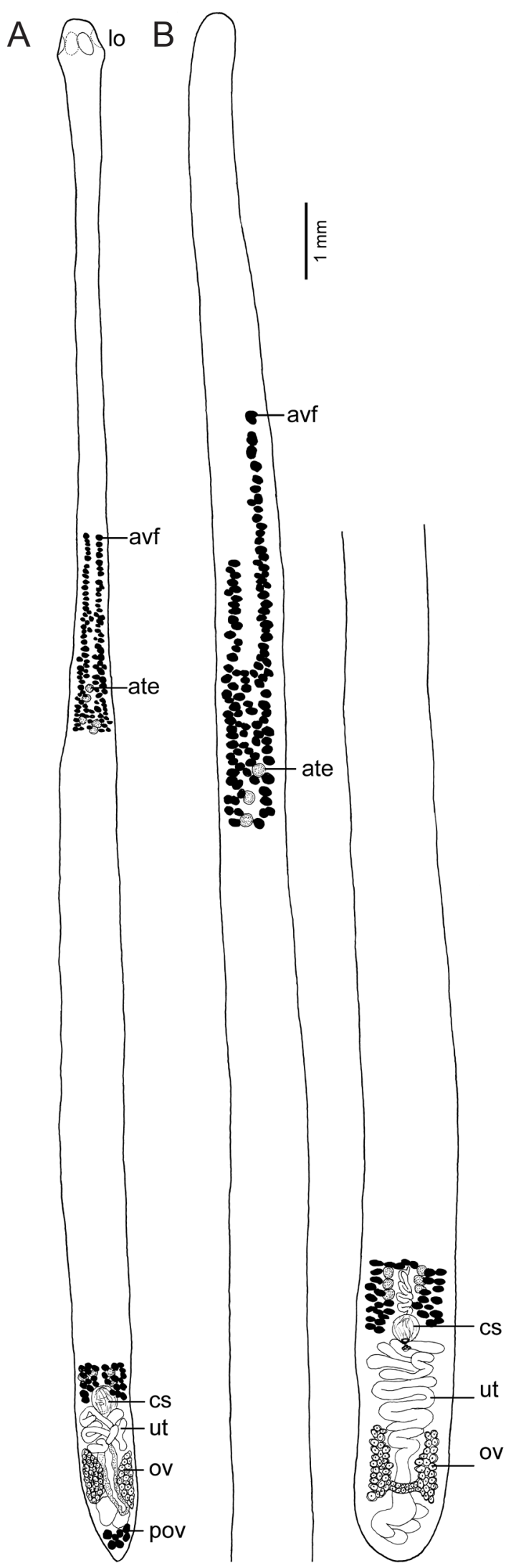

Fig. 2. A - total view of Promonobothrium currani sp. n. from Ictiobus bubalus (paratype, NHMUK London; dorsal view); B - total view of Promonobothrium papiliovarium sp. n. from Erimyzon oblongus (Mitchill) (paratype, IPCAS C-697; ventral view). Abbreviations: ate - anteriormost testes; avf - anteriormost vitelline follicles; cs - cirrus-sac; lo - loculi; ov - ovary; pov - postovarian vitelline follicles; ut - uterus.
Infection rate: Chotard Lake - I. bubalus, prevalence $100 \%(2 / 2)$ (intensity of infection 6-21); I. niger, prevalence $100 \%(1 / 1)$ (intensity of infection 1$)$.

Deposition of specimens: Holotype (complete, whole-mounted specimen collected on 23 March 2012 from I. bubalus; host field No. US 245a), two paratypes (wholemounts, from I. bubalus - No. US 260 and from I. niger No. US 244a - hologenophore), all IPCAS C-629, one paratype (whole-mounted specimen from I. bubalus; host field No. US 206a) deposited at NHMUK (Coll. no. 2016.2.22.1), one voucher (cross section) deposited at NHMUK (Coll. no. 2016.2.22.2), and one paratype (whole-mounted specimen from I. bubalus) deposited at HWML (Coll. no. 101977) and one voucher (sagittal section) deposited at HWML (Coll. no. 101978).

E t y m o lo g y: The species is named after Stephen Curran from the Gulf Coast Research Laboratory, Ocean Springs, Mississippi, for his extraordinary help to two of the authors (MO and RK) in searching for caryophyllideans and other cestodes in spring 2012 and especially for his valuable contributions to fish parasitology.

Remarks. Promonobothrium currani sp. $\mathrm{n}$. is placed in Promonobothrium, as circumscribed recently by Scholz et al. (2015), because it possesses all but one diagnostic character of this genus, especially the scolex with a pair of loculi and two lateral depressions, genital pores separate, $\mathrm{H}$-shaped ovary, uterine coils not extending anterior to the cirrus-sac, preovarian vitelline follicles lateral and median, and presence of an external seminal vesicle (Mackiewicz 1968, 1994). Its placement in Promonobothrium is also strongly supported by molecular data (see Fig. 5).

The most obvious difference between $P$. currani and other species of Promonobothrium is in the presence of postovarian vitelline follicles in the new species and their absence in the other congeners (Fig. 3B). The new species is also readily separated from other congeners by scolex morphology (loculotruncate in the new species vs digitiform-loculate or digitiform in other congeners) (Tables 1, 2). Promonobothrium currani is most similar to $P$. minytremi, but can be distinguished by morphology of the scolex, which is shorter and less conspicuously separated from the remaining body in P. minytremi (Fig. 1A), and in the anterior vitelline follicles and testes, which begin much closer to the anterior extremity in P. minytremi than in the new species (see figs. 1-3 in Mackiewicz 1968 and Table 2 in the present study). Definitive hosts of both species are different, but may occur in sympatry. The new species was found in two species of buffalo (I. bubalus and I. niger), whereas $P$. minytremi is a specific parasite of the spotted sucker (M. melanops).

\section{Promonobothrium papiliovarium sp. n.}

Figs. 1I,J, 2B, 3C,D

ZooBank number for species:

urn:1sid:zoobank.org:act:488AC4B4-9E4B-4264-A909-CBEC67D31408

Description (based on seven whole-mounted specimens from Erimyzon oblongus). Body elongate, with narrow neck, total length of body $17.0-50.5 \mathrm{~mm}$, widened contin- 

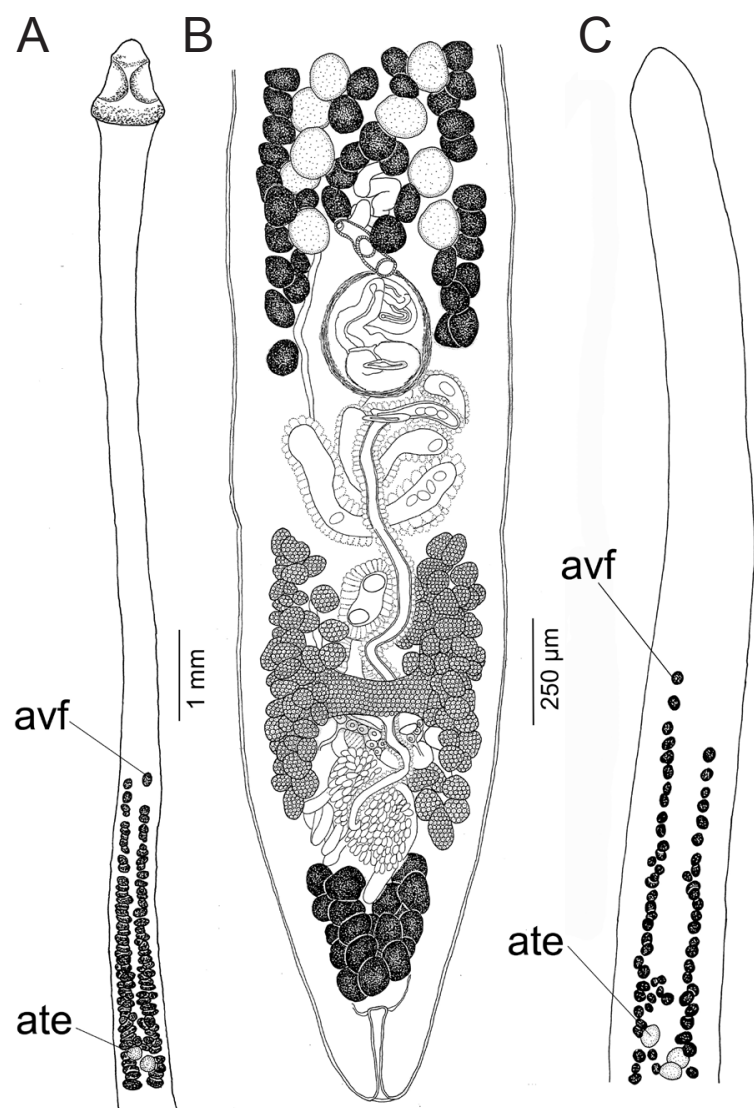

D

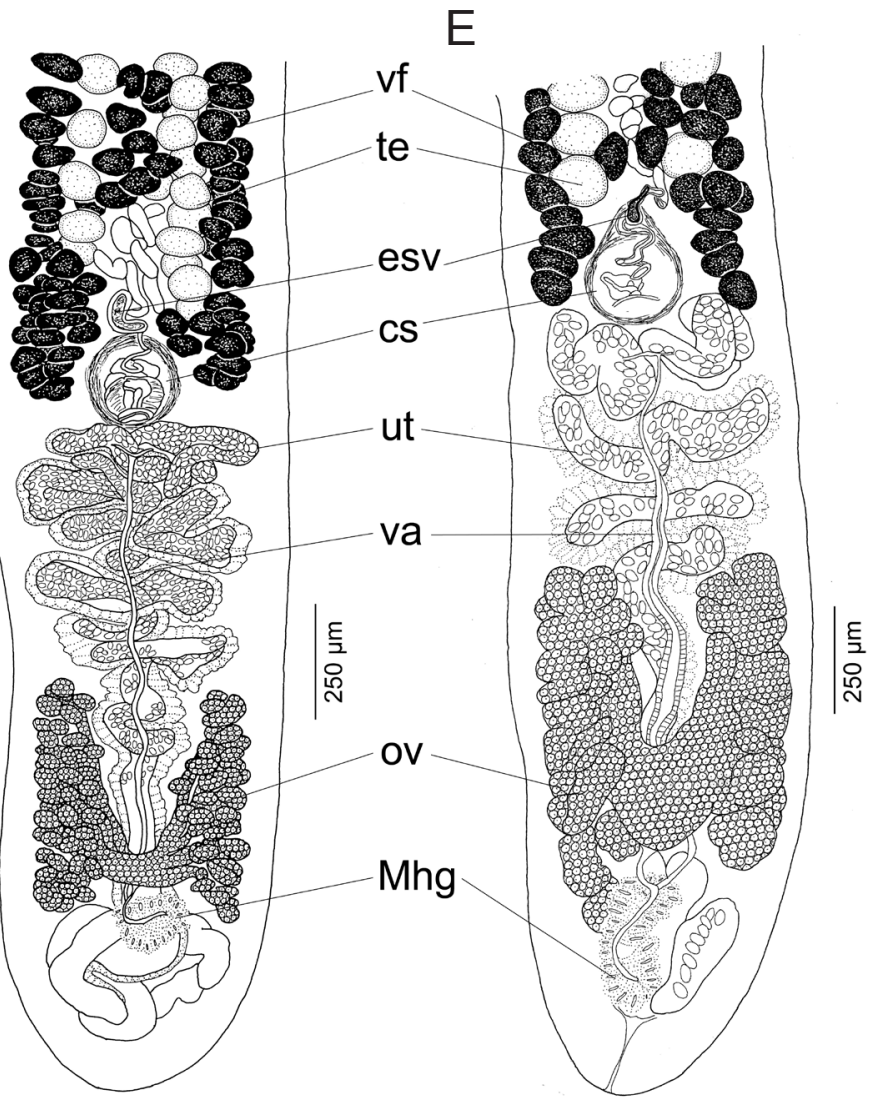

Fig. 3. Line drawings of species of Promonobothrium Mackiewicz, 1968. A-B - Promonobothrium currani sp. n. (holotype, IPCAS C-629), from Ictiobus bubalus (Rafinesque); C-D - Promonobothrium papiliovarium sp. n. (paratype, IPCAS C-697) from Erimyzon oblongus (Mitchill); E - Promonobothrium rogersi (Williams, 1980) comb. n. (paratype USNPC 74855) from Moxostoma poecilurum Jordan. A, C - anterior part of the body with the first vitelline follicles and testes; B, D, E-posterior part of the body, note the presence of external seminal vesicle. Abbreviations: ate - anteriormost testes; avf - anteriormost vitelline follicles; cs - cirrus-sac; esv - external seminal vesicle; Mhg - Mehlis glands; ov - ovary; te - testes; ut - uterus; va - vagina; vf - vitelline follicles.

uously towards posterior end (Fig. 2B). Maximum body width $0.8 \mathrm{~mm}$ at level of cirrus-sac. Surface uniformly covered with acicular filitriches. Inner longitudinal musculature well-developed, formed by small bundles of muscle fibres.

Scolex digitiform (see fig. 5.3 in Mackiewicz 1994 for scolex types), indistinct, not separated from body, 262-623 wide, with a terminal introvert on apex (Figs. 1I,J, 3C). Neck long, 369-694 wide.

Testes medullary (Fig. 3D), 212-253 in number, almost spherical, 114-212 × 94-204 $(\mathrm{n}=50)$; anteriormost testes begin at long distance, $3.4-14.6 \mathrm{~mm}$, posterior to anterior extremity and $1.1-6.3 \mathrm{~mm}$ posterior to anteriormost vitelline follicles. Testicular field ends at level of anterior margin of cirrus-sac (Fig. 3D). Cirrus-sac small, spherical, 276-494 $\times 261-490$ in dorsoventral view, its width representing about $35-40 \%$ of body width. External seminal vesicle present, thick-walled, elongate, forming a few coils (Fig. 3D). Male genital pore separate, anterior to female pore; distance between pores 84-212 (Fig. 3D).

Ovary follicular, medullary, butterfly-shaped (Fig. 3D), with long anterior ovarian arms (364-1001) and short posterior ovarian arms (146-364), total width of ovary 432-969. Vagina tubular, slightly sinuous, form with terminal part of uterus short uterovaginal canal opening by female genital pore posterior to male genital pore. Seminal receptacle absent. Vitelline follicles medullary, numerous, variable in size, $80-189 \times 56-139(\mathrm{n}=50)$, anterior to first testes, begin at long distance, $2.2-8.3 \mathrm{~mm}$, posterior to anterior extremity (Fig. 3C), extend up to level of posterior end of cirrus-sac, absent alongside uterus and ovarian arms (Fig. 3D). Preovarian vitelline follicles lateral and median, surrounding testes, postovarian follicles absent.

Uterus forms several loops between postovarian vitelline follicles and posterior margin of cirrus-sac, never extends anterior to cirrus-sac, joins with vagina to form wide uterovaginal canal. Uterine glands present, well-developed. Eggs operculate, unembryonated, oval, 43-58 $\times$ $32-37(n=30$, intrauterine eggs on whole-mounts).

Type host: Erimyzon oblongus (Mitchill) (Catostomidae: Catostominae).

Site of infection: Anterior intestine.

Type locality: Lake Raleigh, a 77 acre city reservoir in Raleigh, Wake Co., North Carolina, USA.

Deposition of specimens: Holotype (complete, whole-mounted specimen collected on 23 March 2012 and three paratypes (all HWML 33255), USA, two paratypes (IPCAS C-697).

Etymology: The species is named after the typical shape of its ovary (butterfly-shaped) - papilio = butterfly, ovari$\mathrm{um}=$ ovary. 


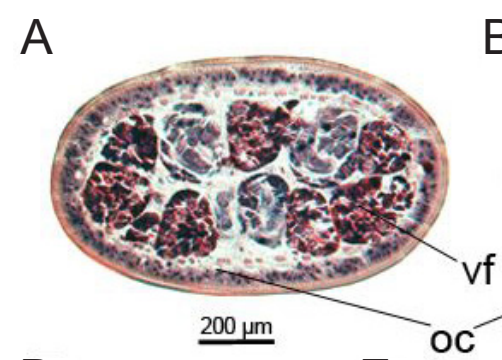

D

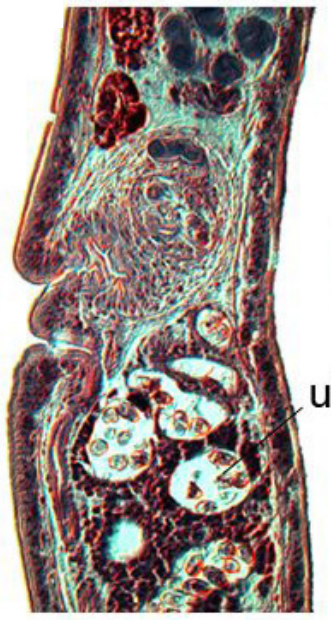

$300 \mu \mathrm{m}$

$\mathrm{E}$

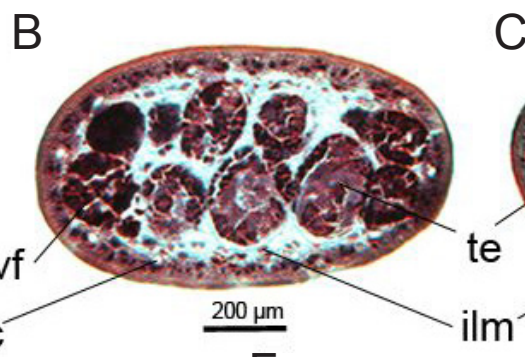

$\mathrm{F}$

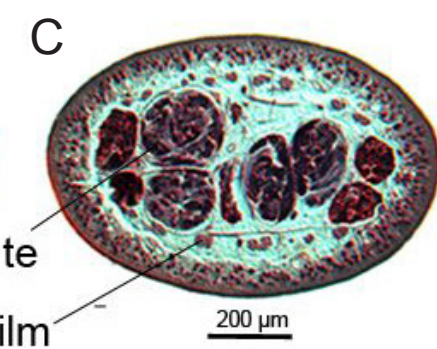

$\mathrm{G}$

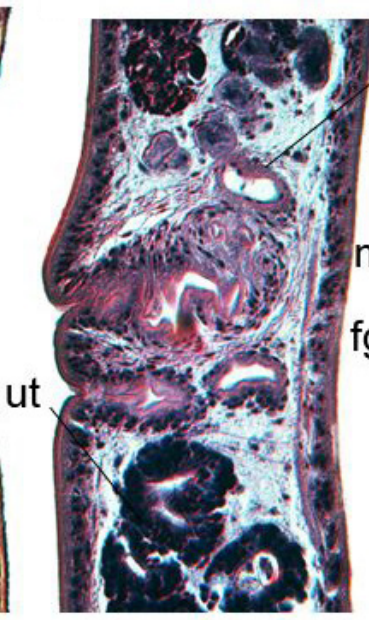

$\underline{300 \mu \mathrm{m}}$

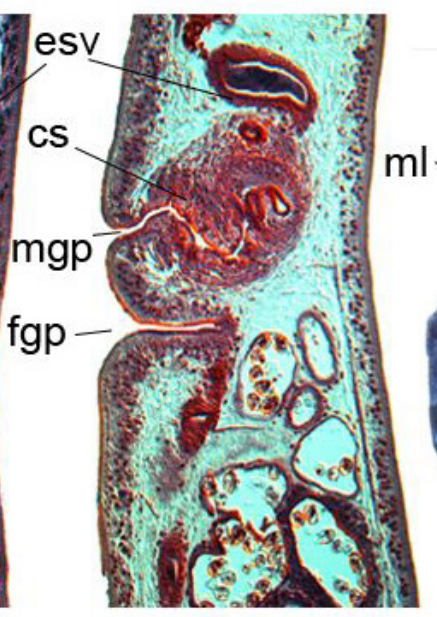

$300 \mu \mathrm{m}$

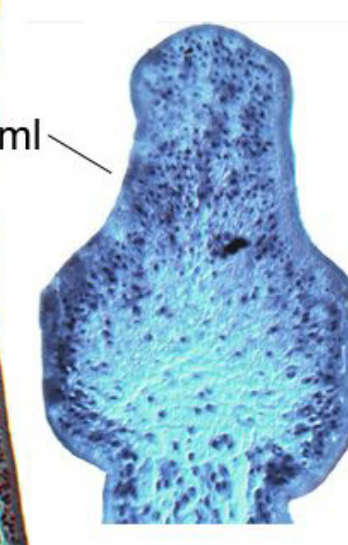

$300 \mu \mathrm{m}$

Fig. 4. Histological sections of species of Promonobothrium Mackiewicz, 1968. A, D - P. currani sp. n. from Ictiobus bubalus (Rafinesque); B, E, G - P. rogersi (Williams, 1980) comb. n. from Carpiodes velifer (Rafinesque); C, F - P. ulmeri (Calentine et Mackiewicz, 1966) from Minytrema melanops (Rafinesque). A-C - cross sections; D-G - sagittal sections. Abbreviations: cs - cirrus-sac; esv - external seminal vesicle; fgp - female gonopore; ilm - inner longitudinal musculature; mgp - male gonopore; ml - median loculus; oc - osmoregulatory canal; te - testes; ut - uterus; vf - vitelline follicles.

Remarks. Examination of specimens from Erimyzon oblongus, identified as Monobothrium ulmeri (HWML 33255), has shown that they represent a new species. Although no ethanol-preserved material was available for molecular analyses, the new species differs so conspicuosly from the species currently placed in Promonobothrium that its validity is well supported. It belongs to Promonobothrium because of its overall morphology, i.e. an elongate body, digitiform scolex with a terminal introvert on the apex, long neck, medullary testes, separate genital pores, uterine coils that do not extend anterior to the cirrus-sac, lateral and median preovarian vitelline follicles, and an external seminal vesicle (Mackiewicz 1968, 1994; the present study).

Promonobothrium papiliovarium sp. n. can be easily distinguished from all congeners by the possession of the uniformly butterfly-shaped ovary, with the anterior lobes much longer than posterior arms. All remaining species of Promonobothrium including $P$. currani sp. n. have an H-shaped ovary, i.e. its anterior and posterior arms are similar in length and shape, even though the ovary of $P$. rogersi may have the posterior lobes markedly shorter than the anterior ones (Fig. 3E).

In addition, $P$. papiliovarium differs from the remaining species of the genus in the shape of the cirrus-sac in dorsoventral view, which is spherical (oval in other species). Promonobothrium papiliovarium is most similar to $P$. $u l$ - meri; both possess an elongate, robust body and a digitiform scolex. However, both species can be distinguished from each other by the shape of the ovary (butterfly- $v s$ $\mathrm{H}$-shaped in P. ulmeri) and cirrus-sac (spherical $v s$ oval in $P$. ulmeri). Moreover, a postovarian vitelline duct is absent in $P$. papiliovarium, whereas it is present in $P$. ulmeri.

The new species may be a specific parasite of Erimyzon oblongus, i.e. it may exhibit oioxenous host specificity.

\section{Interrelationships of species of Promonobothrium based on molecular data}

Phylogenetic analyses based on nearly complete ssrDNA and partial (D1-D3 domains) 1srDNA sequences supported the monophyletic status of the genus Promonobothrium, as well as the monophyly of most of the species of Promonobothrium (only P. rogersi and $P$. ulmeri were represented by a single specimen) (Fig. 5). The phylogenetic position of the genus Promonobothrium within caryophyllideans, as estimated on the basis of current data, remains uncertain, however, the genus tends to form a lineage with the remaining Nearctic caryophyllidean genera included in the analysis (i.e. Glaridacris Cooper, 1920 and Hunterella Mackiewicz et McCrae, 1962) and Archigetes Leuckart, 1878 , independent of the method of phylogenetic inference employed. Similarly to the statistically weakly supported phylogenetic position of Promonobothrium within the Caryophyllidea, the interrelationships within the genus 


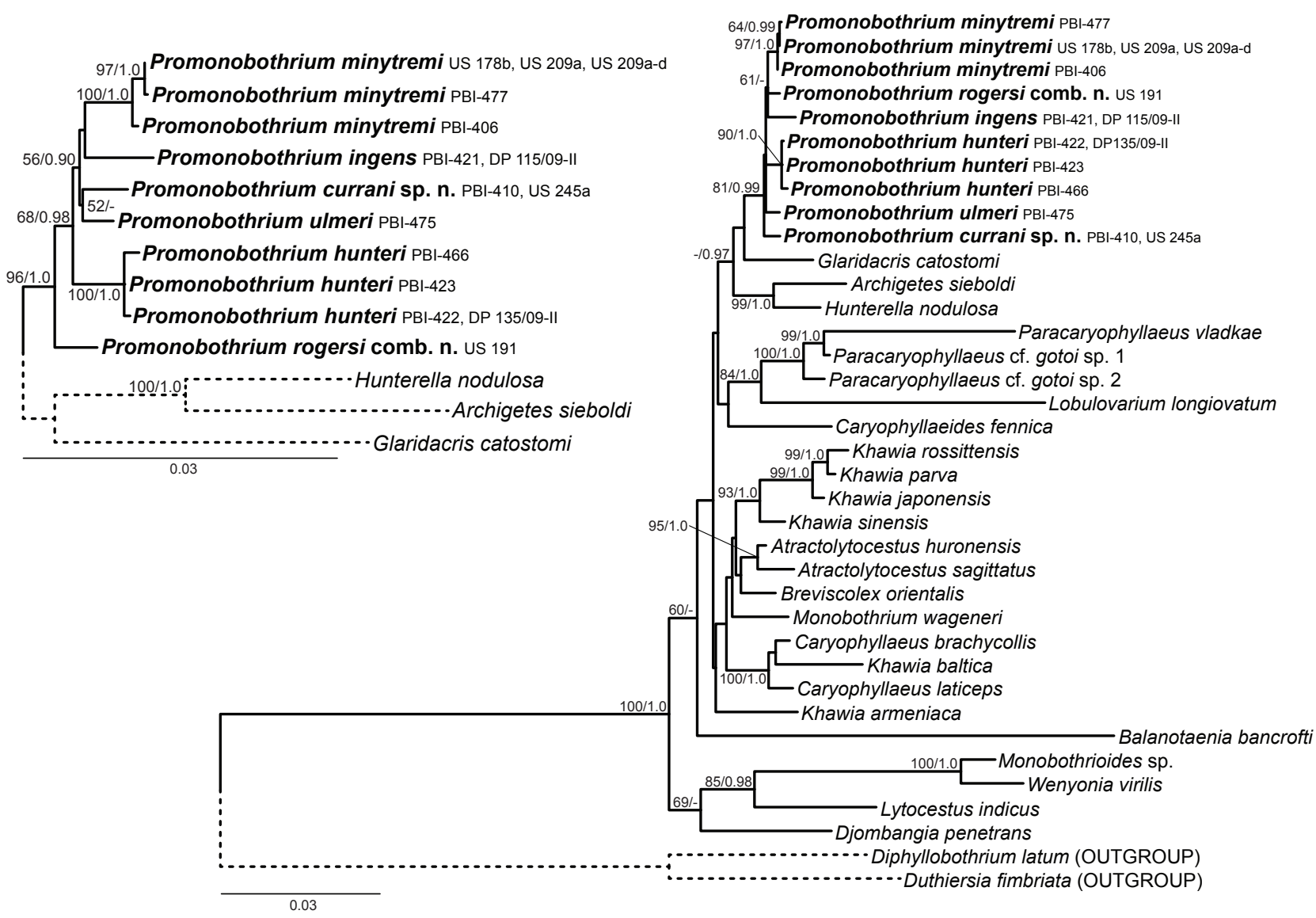

Fig. 5. Best Maximum likelihood estimates based on analyses of concatenated ssrDNA + lsrDNA genes analysed as separate partitions in GARLI. Phylogenetic position of Promonobothrium Mackiewicz, 1968 within the Caryophyllidea (right) and the interrelationships of species of Promonobothrium (left). Partitioning scheme and models of nucleotide evolution employed were: $\operatorname{ssrDNA}(\mathrm{GTR}+\mathrm{I}+\Gamma)$, lsrDNA $($ GTR $+\mathrm{I}+\Gamma)$ (right) and ssrDNA $($ GTR + I), 1 srDNA $($ GTR + I $+\Gamma)($ left $)$; model parameters were estimated separately for each partition. Nodal values indicate ML bootstrap supports $>50$ and Bayesian posterior probabilities $>0.9$. Branch length scale bars indicate number of substitutions per site. Species of Promonobothrium in bold.

remain uncertain and prone to change depending on the dataset analysed (compare Fig. 5 topologies based on the dataset including all caryophyllideans - right - and dataset limited to Nearctic genera - left).

\section{DISCUSSION}

Promonobothrium, for several decades a monotypic genus, now belongs to the group of species-rich Nearctic genera of caryophyllidean cestodes. Scholz et al. (2015) transferred five species, originally placed in Monobothrium, to Promonobothrium based on morphological and molecular evidence. In the present paper, another species is transferred and two new species are described. In the Nearctic region, only two other caryophyllidean genera contain a comparable number of species, i.e. Isoglaridacris Mackiewicz, 1965 (with 10 described species) and Biacetabulum Hunter, 1927 (9 species) (Schmidt 1986, Hoffman 1999, Caira et al. 2012).

The main novelty in the amended generic diagnosis presented in this study is that the species of Promonobothrium either possess or lack postovarian vitelline follicles. The presence or absence of postovarian vitelline follicles is regarded as an important taxonomic character that is rarely shared by species of the same genus (Schmidt 1986, Mack- iewicz 1994), but one of the new species described here, $P$. currani, is typified by such postovarian vitelline follicles. Interestingly, $P$. hunteri and $P$. ulmeri, both usually without postovarian vitelline follicles (exceptionally, a few follicles are present in P. hunteri-Mackiewicz 1963; present study), possess a postovarian loop of the vitelloduct (Mackiewicz 1963). Moreover, P. rogersi has both states; some specimens lack postovarian vitelline follicles, whereas others can possess 1-14 postovarian vitelline follicles (Williams 1980; present study).

This demonstrates intraspecific variability in some species of Promonobothrium in relation to this otherwise stable and taxonomically important morphological trait (Mackiewicz 1994). Based on the data available, it can be concluded that the presence or absence of postovarian vitelline follicles can be still considered as a key taxonomic character at the generic level in all but one (Nearctic) zoogeographical regions (Mackiewicz 1994). Our data suggest that this character should be used with caution when differentiating genera of Nearctic caryophyllideans.

The shape of the scolex represents a useful morphological characteristic widely used for generic classification of caryophyllidean cestodes (Mackiewicz 1972) and in some cases also for species identification (Oros et al. 2010). In 
contrast, great variety of scolex shapes has been found within the most speciose genera, i.e. Khawia Hsü, 1935 and Caryophyllaeus Gmelin, 1790 (see Oros et al. 2010, Scholz et al. 2011, Barčák et al. 2014, Hanzelová et al. 2015).

Scanning electron micrographs (SEM) have demonstrated a variety of scolex types, with three scolex types present in species of Promonobothrium. The type species $P$. minytremi, along with $P$. rogersi and the newly described $P$. currani, possesses a loculotruncate scolex, i.e. distinct scolex, much wider than the neck, with a pair of shallow median loculi and two lateral depressions (Fig. 1A,E-H). Other congeners possess a scolex not distinctly separated from the remaining body. Promonobothrium ingens possesses a scolex with a pair of distinct loculi, i.e. digitiform-loculate, whereas $P$. hunteri, $P$. papiliovarium and $P$. ulmeri have a scolex without distinct loculi, i.e. digitiform, but they differ from each other in the morphology of the reproductive system (see key to species identification below). In contrast, the scanning electron micrographs have also revealed the presence of a terminal introvert on apex in all studied species of Promonobothrium (see Fig. 1), which may have functional significance in attaching worms to host mucosa.

The present study has demonstrated a significant degree of phenotypic variability of the scolices at the interspecific level of Promonobothrium, similarly as observed by Scholz et al. (2011) in Khawia. Recently, morphological and molecular data have even revealed high intraspecific phenotypic plasticity in the morphology of the anterior part of the body of Caryophyllaeus laticeps (Pallas, 1781) as well as in congener C. brachycollis Janiszewska, 1953, both parasites of freshwater cyprinids in the Palaearctic (see Barčák et al. 2014, Hanzelová et al. 2015). Therefore, the taxonomic importance of morphological characteristics related to the scolex morphology in caryophyllidean cestodes should be weighed on the basis of combined detailed morphological, molecular and ecological studies.

Except for the genera Pliovitellaria Fischthal, 1951 and Wenyonia Woodland, 1923, which have the ovary near the middle of the body, the ovary of all caryophyllideans is situated near the posterior part of the body (Mackiewicz 1972, Schaeffner et al. 2011). Two different ovary forms are present in the same genus only rarely, such as in Isoglaridacris (Mackiewicz 1972) and in Khawia, the species of which possess both an H-shaped and inverted A-shaped (posterior arms connected) ovary (Scholz et al. 2011). In the present study, two different shapes of the ovary were also recognised among species of Promonobothrium, i.e. the most common $\mathrm{H}$-shaped ovary in five species and a butterfly-shaped ovary in P. papiliovarium (Fig. 3D).

As has been shown in previous studies (Oros et al. 2010, Scholz et al. 2011, Barčák et al. 2014, Hanzelová et al. 2015), and also demonstrated in species of Promonobothrium by the present study, some key discriminating features (scolex morphology, anterior extent of testes and vitelline follicles, postovarian vitelline follicles, shape of the ovary) are subjected to a significant degree of phenotypic variability at the intrageneric or even intraspecific level. Therefore, an integrative approach combining morphology, molecular analyses and ecological data on hosts and their distribution should be used in taxonomic studies (Dayrat 2005, Schlick-Steiner et al. 2010).

Among the species of Promonobothrium, different degrees of host specificity apparently exist; $P$. minytremi from M. melanops and $P$. papiliovarium from E. oblongus are oioxenous, whereas $P$. hunteri, $P$. ingens, $P$. ulmeri, $P$. currani and $P$. rogersi are probably (meta)stenoxenous. Of these, $P$. ingens and $P$. rogersi are distributed across both catostomine and ictiobine lineages of suckers, whereas other (meta)stenoxenous species appear to be either associated with catostomines (as in $P$. ulmeri) or ictiobines (as in $P$. currani). However, several host records have not been confirmed by the present study and may represent accidental infections or misidentifications (see Synopsis section for host records).

The family Catostomidae is a diverse group of benthic freshwater fishes forming preponderant fish populations in North America, where they comprise around 7\% of the freshwater ichthyofauna (Jenkins and Burkhead 1993). According to the morphological, biochemical, early life history and molecular data, catostomids can be divided into four subfamilies: Catostominae, Cycleptinae, Ictiobinae and Myxocyprininae (Nelson 2006). Buffalofish (Ictiobinae), including Ictiobus bubalus and I. niger that harbour Promonobothrium currani, inhabit pools, backwaters and main channels of small to large rivers in the Mississippi River basin and Lake Michigan drainage. Spotted sucker (Minytrema melanops, subfamily Catostominae) inhabits small to medium rivers over clay, sand or gravel, being only occasionally found in large rivers and impoundments (Page and Burr 1991).

According to recent phylogenetic analyses (Sun et al. 2007, Doosey et al. 2010, Chen and Mayden 2012), Ictiobus Rafinesque and Carpiodes Rafinesque, which belong to the monophyletic subfamily Ictiobinae, represent two of the oldest lineages of suckers. Within the most derived subfamily Catostominae, phylogenetic position of M. melanops is not well resolved (Doosey et al. 2010, Chen and Mayden 2012). Members of the genus Promonobothrium have been reported also from the most species-rich subfamily Catostominae that contains four tribes (Chen and Mayden 2012). Species of Promonobothrium are known from all of them, specifically from five of nine recognised genera, i.e. Erimyzonini (Minytrema and Erimyzon), Catostomini (Catostomus), Thoburniinae (Hypentelium) and Moxostomatini (Moxostoma). Distant phylogenetic position of hosts of both of these species of Promonobothrium thus suggests that they may present an example of speciation of congeneric tapeworms in phylogenetically distantly related suckers, i.e. without clear patterns of co-phylogenesis of the host and its parasite.

\section{Key to the identification of species of Promonobothrium}

To facilitate identification, a key to all species of Promonobothrium recognised as valid is presented. The key is based primarily on the gross morphology and a few char- 
acteristics of the scolex and internal organs. However, species identification should be verified using individual species diagnoses provided in the morphological descriptions of the respective species.

1 Scolex distinct, truncate, i.e. scolex markedly wider than neck region 2

- Scolex indistinct, digitiform, i.e. scolex not wider, or only slightly wider than neck region 4

2 Anteriormost testes always well posterior to anteriormost vitelline follicles 3

- Anteriormost testes anterior to anteriormost vitelline follicles or on same level (in some cases close posterior to anteriormost vitelline follicles)

Promonobothrium rogersi comb. $\mathrm{n}$.

3 Postovarian vitelline follicles absent; parasite of Minytrema melanops .......... Promonobothrium minytremi

- Postovarian vitelline follicles present; parasites of Ictiobus spp. ........ Promonobothrium currani sp. n.

4 Scolex with a pair of distinct loculi, digitiform-loculate Promonobothrium ingens

- Scolex lacking distinct loculi, digitiform 5

5 Ovary H-shaped, i.e. with almost equal length of ovarian arms 6

- Ovary butterfly-shaped, i.e. with long anterior ovarian arms and short posterior ovarian arms; parasite of Erimyzon oblongus

Promonobothrium papiliovarium $\mathrm{sp} . \mathrm{n}$.

6 Body large, robust worms (up to about $50 \mathrm{~mm}$ ), neck long, more than 300 testes

Promonobothrium ulmeri

- Body more slender, smaller worms (up to about 20 $\mathrm{mm}$ ), neck short, fewer than 300 testes 7
7 Postovarian loop of vitelloduct present, postovarian vitelline follicles may be present

Promonobothrium hunteri

- Postovarian loop of the vitelloduct absent, postovarian vitelline follicles absent 8

$8 *$ Osmoregulatory canals number 8 , more than 250 testes, worms together in mucosal pits

Promonobothrium fossae

_ * Osmoregulatory canals number 16, less than 180 testes, worms not in mucosal pits

\section{Promonobothrium mackiewiczi}

* because of the lack of newly collected material of $P$. fossae and $P$. mackiewiczi, the key differential characters used herein are based on the original species descriptons provided by Williams (1974)

Acknowledgements. M.O. and R.K. are much obliged to Isaure de Buron and Vincent A. Connors (College of Charleston, South Carolina), Steve Curran, Eric Pulis and Robin Overstreet (Gulf Coast Research Laboratory, Mississippi), Megan Bean and Peterson T. Bean (Texas Parks and Wildlife Department, Texas) for invaluable help during material collection in 2012. Andrea Waeschenbach (Natural History Museum, London) kindly provided unpublished sequences of four isolates of Promonobothrium spp. and curators Eric P. Hoberg, Patricia Pilitt (USNPC) and Gábor Rácz (HWML) made it possible to study specimens from their collections. Two anonymous reviewers provided helpful and insightful comments that helped improve considerably the quality of this manuscript. Stay of M.O. in North America in 2013 was enabled by the Fulbright Foundation. The present study was also supported by the Slovak Research and Development Agency (projects nos. APVV-0653-11 and LPP 0171-09), Grant Agency VEGA (No. 2/0159/16), Institute of Parasitology (RVO: 60077344) and Czech Science Foundation (project No. P505/12/ G112). This work was undertaken within the framework of a project of the Research \& Development Operational Programme funded by the ERDF (code ITMS: 26220120022) (0.2) and the National Science Foundation, USA (PBI awards 0818696 and 0818823). A.C. acknowledges support from a St. Norbert College, Faculty Development Summer Grant.

\section{REFERENCES}

Bangham R.V., Venard C.E. 1942: Studies on parasites of Reelfoot lake fish. IV. Distribution on studies and checklist of parasites. J. Tennessee Acad. Sci. 17: 22-38.

BarčÁk D., Oros M., Hanzelová V., Scholz T. 2014: Phenotypic plasticity in Caryophyllaeus brachycollis Janiszewska, 1953 (Cestoda: Caryophyllidea): does fish host play a role? Syst. Parasitol. 88: 153-166.

Bazsalovicsová E., Králová-Hromadová I., Brabec J., HaNzelová V., Oros M., Scholz T. 2014: Conflict between morphology and molecular data: a case of the genus Caryophyllaeus (Cestoda, Caryophyllidea), monozoic tapeworm of cyprinid fishes. Folia Parasitol. 61: 346-352.

Brabec J., Scholz T., Králová-Hromadová I., BazsalovICSOVÁ E., OLsON P.D. 2012: Substitution saturation and nuclear paralogs of commonly employed phylogenetic markers in the Caryophyllidea, an unusual group of non-segmented tapeworms (Platyhelminthes). Int. J. Parasitol. 42: 259-267.

Caira J.N., Jensen K., Barbeau E. 2012: Global Cestode Database. World Wide Web electronic publication, www.tapewormdb.uconn.edu, 12/2015.
Calentine R.L. 1967: Larval development of four caryophyllaeid cestodes. Proc. Iowa Acad. Sci. 72: 418-424.

Calentine R.L., Mackiewicz J.S. 1966: Monobothrium ulmeri n. sp. (Cestoda: Caryophyllaeidae) from North American Catostomidae. Trans. Am. Microsc. Soc. 85: 516-520.

Chen W.-J., Mayden R.L. 2012: Phylogeny of suckers (Teleostei: Cypriniformes: Catostomidae): further evidence of relationships provided by the single-copy nuclear gene IRBP2. Zootaxa 3586 : $195-210$.

Chervy L. 2009: Unified terminology for cestode microtriches: a proposal from the International Workshops on Cestode Systematics in 2002-2008. Folia Parasitol. 56: 199-230.

Dayrat B. 2005: Towards integrative taxonomy. Biol. J. Linnean Soc. 85: 407-415.

Doosey M.H., Bart H.L., Saitoh K., Miya M. 2010: Phylogenetic relationships of catostomid fishes (Actinopterygii: Cypriniformes) based on mitochondrial ND4/ND5 gene sequences. Mol. Phyl. Evol. 54: 1028-1034.

Grimes L.R., Miller G.C. 1975: Caryophyllaeid cestodes in the creek chubsucker, Erimyzon oblongus (Mitchill), in North Carolina. J. Parasitol. 61: 973-974. 
Haley D.R., Barger M.A. 2014: A new genus and species of caryophyllaeid (Cestoda: Caryophyllidea) from spotted suckers, Minytrema melanops (Catostomidae), in the Big Thicket national preserve, Texas, U.S.A. Comp. Parasitol. 81: 23-26.

Hanzelová V., Oros M., BarčÁk D., Miklisová D., Kirin D., Scholz T. 2015: Morphological polymorphism in tapeworms: redescription of Caryophyllaeus laticeps (Pallas, 1781) (Cestoda: Caryophyllidea) and characterisation of its morphotypes from different fish hosts. Syst. Parasitol. 90: 177-190.

Hoffman G.L. 1999: Parasites of North American freshwater fishes. Second Edition. Comstock Publishing Associates, Cornell University Press, Ithaca, New York, 539 pp.

Hunter G.W. 1927: Notes on the Caryophyllaeidae of North America. J. Parasitol. 14: 16-26.

Hunter G.W. 1930: Studies on the Caryophyllaeidae of North America. Illin. Biol. Monogr. 11 (1927), 186 pp.

Jenkins R.E., Bur k HeAd N.M. 1993: Freshwater Fishes of Virginia. American Fisheries Society. Bethesda, Maryland, 1079 pp.

Katoh K., Standley D.M. 2013: MAFFT multiple sequence alignment software version 7: improvements in performance and usability. Mol. Biol. Evol. 30: 772-780.

Kearse M., Moir R., Wilson A., Stones-Havas S., Cheung M., Sturrock S., Buxton S., Cooper A., Markowitz S., Duran C., Thierer T., Ashton B., Mentuies P., DrumMOND A. 2012: Geneious Basic: an integrated and extendable desktop software platform for the organization and analysis of sequence data. Bioinformatics 28: 1647-1649.

Králová-Hromadová I., ŠtefkKa J., Špakulová M., Orosová M., Bombarová M., Hanzelová V., Bazsalovicsová E., Scholz T. 2010: Intra-individual internal transcribed spacer 1 (ITS1) and ITS2 ribosomal sequence variation linked with multiple rDNA loci: a case of triploid Atractolytocestus huronensis, the monozoic cestode of common carp. Int. J. Parasitol. 40: $175-181$.

Lanfear R., Calcott B., Ho S.Y.W., Guindon S. 2012: Partitionfinder: combined selection of partitioning schemes and substitution models for phylogenetic analyses. Mol. Biol. Evol. 29: $1695-1701$

MackiewiCZ J.S. 1963: Monobothrium hunteri sp. n. (Cestoidea: Caryophyllaeidae) from Catostomus commersoni (Lacépède) (Pisces: Catostomidae) in North America. J. Parasitol. 49: 723-730.

MACKIEWICZ J.S. 1968: Two new caryophyllaeid cestodes from the spotted sucker, Minytrema melanops (Raf.) (Catostomidae). J. Parasitol. 54: 808-813.

Mackiewicz J.S. 1972: Caryophyllidea (Cestoidea): a review. Exp. Parasitol. 31: 417-512.

MACKIEwiCZ J.S. 1981: Caryophyllidea (Cestoidea): evolution and classification. Adv. Parasitol. 19: 139-206.

Mackiewicz J.S. 1994: Order Caryophyllidea van Beneden in Carus, 1863. In: L.F. Khalil, A. Jones and R.A. Bray (Eds.), Keys to the Cestode Parasites of Vertebrates. CAB International, Wallingford, pp. 21-43.

MackiewiCZ J.S. 2003: Caryophyllidea (Cestoidea): molecules, morphology and evolution. Acta Parasitol. 48: 143-154.

Nelson J.S. 2006: Fishes of the World. John Wiley and Sons, New York, $624 \mathrm{pp}$.

Oros M., Scholz T., Hanzelová V., Mackiewicz J.S. 2010: Scolex morphology of monozoic cestodes (Caryophyllidea) from the Palaearctic Region: a useful tool for species identification. Folia Parasitol. 57: 37-46.

Page L.M., Burr B.M. 1991: A Field Guide to Freshwater Fishes of North America North of Mexico. Houghton Mifflin Company, Massachusetts, $432 \mathrm{pp}$.

Pleijel F., Jondelius U., Norlinder E., Nygren A., Oxelman B., Schander C., Sundberg P., Thollesson M. 2008: Phylogenies without roots? A plea for the use of vouchers in molecular phylogenetic studies. Mol. Phylogen. Evol. 48: 369-371.

Ronquist F., Teslenko M., van der Mark P., Ayres D.L., Darling A., Höhna S., Larget B., Liu L., Suchard M.A., HuelsenbeCK J.P. 2012: MrBayes 3.2: efficient Bayesian phylogenetic inference and model choice across a large model space. Syst. Biol. 61: 539-542.

Schaeffner B.C., JirkŮ M., Mahmoud Z.N., Scholz T. 2011: Revision of Wenyonia (Cestoda: Caryophyllidea) from Synodontis catfish in Africa. Syst. Parasitol. 79: 83-107.

Schlick-Steiner B.C. Steiner F.M., Seifert B., Stauffer C., Christian E., Crozier R.H. 2010: Integrative taxonomy: a multisource approach to exploring biodiversity. Annu. Rev. Entomol. 55: 421-438.

SCHмIDT G.D. 1986: CRC Handbook of Tapeworm Identification. CRC Press, Boca Raton, Florida, 675 pp.

Scholz T., Brabec J., Králová-Hromadová I., Oros M., Bazsalovicsová E., Ermolenko A., Hanzelová V. 2011: Revision of Khawia spp. (Cestoda: Caryophyllidea), parasites of cyprinid fish, including a key to their identification and molecular phylogeny. Folia Parasitol. 58: 197-223.

Scholz T., Choudhury A. 2014: Parasites of freshwater fishes in North America: why so neglected? J. Parasitol. 100: 26-45.

Scholz T., Oros M., Choudhury A., Brabec J., WaeschenBACH A. 2015: New circumscription of freshwater fish parasites Monobothrium Diesing, 1863 and Promonobothrium Mackiewicz, 1968 (Cestoda: Caryophyllidea) using morphological and molecular evidence. J. Parasitol. 101: 29-36.

Špakulová M., Orosová M., Mackiewicz J.S. 2011: Cytogenetics and chromosomes of tapeworms (Platyhelminthes, Cestoda). Adv. Parasitol. 74: 177-230.

Sun Y.H., Xie C.X., Wang W.M., Liu S.Y., Treer T., Chang M.M. 2007: The genetic variation and biogeography of catostomid fishes based on mitochondrial and nucleic DNA sequences. J. Fish Biol. 70: 291-309.

Williams D.D. 1977: Biacetabulum oregoni sp. n. (Cestoda: Caryophyllidea) from Catostomus macrocheilus. Iowa State J. Res. 52: 397-400.

Williams D.D. 1978: A key to caryophyllaeid cestodes of Wisconsin fishes. Iowa State J. Res. 51: 471-477.

Williams E.H. 1974: Two new species of Monobothrium (Cestoda: Caryophyllaeidae) from catostomid fishes of the southeastern United States. Trans. Am. Fish. Soc. 103: 610-615.

Williams E.H. 1980: Rogersus rogersi gen. et sp. n. (Cestoda: Caryophyllaeidae) from the blacktail redhorse, Moxostoma poecilurum (Jordan) (Osteichthyes), in the soustheastern United States. J. Parasitol. 66: 564-568.

ZwICKL D.J. 2006: Genetic algorithm approaches for the phylogenetic analysis of large biological sequence datasets under the maximum likelihood criterion. $\mathrm{PhD}$ thesis, University of Texas at Austin, $115 \mathrm{pp}$. 